\title{
Professor Doutor Luiz Marino Bechelli
}

25 de março de 1912

\& 16 de agosto de 2004

O Prof. Luiz Marino Bechelli, nascido em 25 de março de 1912, em Pirambóia, São Paulo, formou-se em medicina pela $\mathrm{Fa}$ culdade de Medicina da Universidade de São Paulo - FMUSP, em 1933. Seus pendores para a investigação clínica manifestaram-se na fase de estudante quando foi auxiliar acadêmico do Posto de Sífilis Arnaldo Vieira de Carvalho, chegando a vice-chefe no sexto ano do curso médico. Participou também de atividades estudantis como secretário do Departamento Científico e Tesoureiro (presidente da Caixa do Livro), ambos do Centro Acadêmico Oswaldo Cruz. Campeão de bola ao

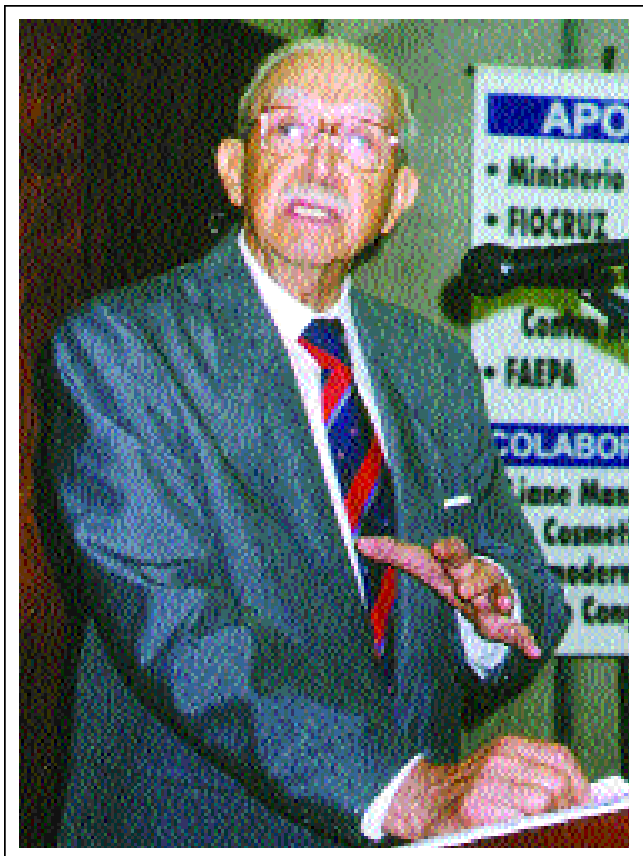

O 25th March 1912

\& 16th August 2004

Prof. Luiz Marino Bechelli, born on March 25th, 1912, in Piramboia, Sao Paulo, graduated in medicine at the Faculty of Medicine, University of Sao Paulo FMUSP, in 1933. His inclination towards clinical investigation became apparent while still a student, when he was an academic aid at the Arnaldo Vieira de Carvalho Syphilis Unit, where he became deputy head in the sixth year of the medical course. He also participated in student activities as secretary of the Scientific Depar tment and Treasurer (president of the Cash Book), both pertaining to the Oswaldo Cruz Academic cesto na equipe da Faculdade de Medicina, sempre amou o esporte, em todas as suas modalidades. Torcia pelo Palmeiras e jogava tênis. Era amante de arte, literatura e música, desde a popular até a clássica.

Fez tese de doutoramento em maio de 1934 e, desde então, dedicou-se ao ensino da dermatologia e à investigação em hansenologia, no exercício da função de assistente extranumerário da FMUSP, onde defendeu a livredocência no ano de 1947.

A convite do Prof. Dr. Zeferino Vaz, diretor e fundador da Faculdade de Medicina de Ribeirão Preto da Universidade de São Paulo - FMRP/USP, o Prof. Bechelli assumiu em agosto de 1957 a responsabilidade de organizar e desenvolver o Departamento de Dermatologia daquela faculdade. Livre-docente de dermatologia da Faculdade de Medicina da Universidade de São Paulo, abdicou de sua clínica particular para exercer essa atividade em regime de tempo integral com dedicação exclusiva a Docência, Assistência e Pesquisa, inicialmente como professor contratado e passando, em abril de 1961, a professor catedrático de dermatologia, após a realização do primeiro concurso de cátedra da FMRP/USP.

A carreira de pesquisador e professor de dermatologia foi programada de forma metódica e construtiva, baseada em intensa atividade assistencial associada ao investimento em sua formação acadêmica, com o objetivo de ampliar e atualizar sua especialidade. Nesse sentido, realizou os cursos de pós-graduação: New York Skin and Cancer, na Columbia University, e
Center. Basket ball champion in the Faculty of Medicine team, he always loved sport, in all its modalities. He supported Palmeiras soccer team and played tennis. He appreciated art, literature and music, from popular to classic.

His doctoral thesis was accepted in May 1934 and, ever since, he was devoted to the teaching of dermatology and investigation in leprology, and while working as an informal assistant at FMUSP, he presented the findings of his post-doctoral studies in the year of 1947.

Invited by Prof. Dr. Zeferino Vaz, director and founder of the Faculty of Medicine of Ribeirao Preto, University of Sao Paulo - FMRP/USP, in August 1957, Prof. Bechelli assumed the responsibility of organizing and developing the Dermatology Department at that university. Post-doctor professor of dermatology at the Faculty of Medicine, University of São Paulo, he left his private clinic to exert full time practice and exclusive dedication to Teaching, Assistance and Research and research, first as a lecturer, and later as a dermatology professor, hired by in FMRP/USP in April 1961, after public competition.

This tenure track in teaching and research of dermatology was planned in a methodical and constructive manner, based on intense volunteer work combined with investments in his academic development, with the objective of amplifying and updating his expertise. In that sense, he underwent the following postgraduate courses: New York Skin And Cancer, at Columbia University, and Epidemiology of Infectious Diseases and Biostatistics, in 
Epidemiologia de Moléstias Infecciosas e Bioestatística, na Western Reserve University, em Cleveland, EUA, para o qual recebeu bolsa do Institute of Inter American Affairs e da Leonard Wood Memorial, no período de julho de 1944 a julho de 1945. A atualização na especialidade foi mantida com estágios no Hôpital St. Louis (Paris, França) e em visitas a clínicas de dermatologia na Europa, América do Norte e América do Sul. Foi um dos pioneiros no país ao escrever, em 1960, com a colaboração do Prof. Guilherme V. Curban, da FMUSP, o livro intitulado Compêndio de Dermatologia, que se constituiu em fonte atualizada de ensinamentos para os estudantes de medicina e dermatologistas em formação, até sua sexta edição no ano de 1988.

Paralelamente, ingressou no Departamento de Lepra, em São Paulo, inicialmente como médico clínico estagiário do sanatório de Cocais e, após concurso, como seu diretor clínico. No Departamento de Lepra de São Paulo, considerado nas décadas de 1930 a 1950 um dos maiores centros de investigações de hanseníase no mundo, exerceu funções de destaque, como chefe da Unidade de Epidemiologia, diretor da Divisão dos Sanatórios e, depois, dos Dispensários de Lepra. A profundidade dos conhecimentos profissionais adquiridos no campo da hansenologia, resultou em sua maior contribuição científica, com cerca de 300 publicações no país e no exterior, e em seu reconhecimento como um dos maiores hansenólogos do mundo.

Além desses cargos administrativos, exerceu a função de diretor, em exercício, concomitante à de chefia do Departamento de Dermatologia, ambas na FMRP/USP. Sua carreira culminou com o reconhecimento internacional de sua atividade como hansenólogo, durante o período de 30 de dezembro de 1961 a 30 de junho de 1972, no posto de expert e chefe da Leprosy Unit from World Health Organization, após concurso internacional em Genebra, na Suíça.

Sua profícua produção acadêmica foi coroada com contribuições na descrição clínica evolutiva e avaliação epidemiológica da endemia da hanseníase em nosso país. Nesse sentido, foram publicados o Tratado Brasileiro de Hansenologia e o Compêndio de Leprologia, ambos em coautoria com Abrahão Rotberg, os quais constituem um marco no estudo da doença. O Prof. Bechelli foi também um dos líderes na proposição da Classificação Brasileira da Hanseníase, que passou a ser adotada em nível mundial. Em meio aos 275 trabalhos que publicou, muitos dos quais com contribuições originais, alguns com ultramicroscopia de dermatoses, teve 12 monografias premiadas. Além das contribuições relatadas, merecem destaque a autoria dos capítulos "Premunition der Lepra" e "Behandlung der Lepra" no monumental Handbuch der Haut und Geschlechtskrankheiten, de Jadassohn, reeditado por Marchionini. No livro de Veronesi, sobre doenças infecciosas e parasitárias, escreveu os capítulos sobre lepra, bouba e pinta. Colaborou ainda em outros tratados estrangeiros como the Western Reserve University, in Cleveland, USA, for which he received a grant from the Institute of Inter American Affairs and Leonard Wood Memorial, from July 1944 to July 1945. Updating in the specialty was assured with courses at Hopital St. Louis (Paris, France) and visits to dermatology clinics in Europe, North and South America. He was one of the pioneers in the country when writing, in 1960, with the collaboration of Prof. Guilherme V. Curban, FMUSP, the book entitled Compendium of Dermatology, that constituted an updated source of teaching for the medicine students and dermatologists under his tuition, until its sixth edition in 1988.

On a parallel basis, he entered the Department of Leprosy, in São Paulo, initially as a trainee clinical doctor of the sanatorium of Cocais and, after public competition, as its clinical director. In the Department of Leprosy of São Paulo, which was considered in the decades from 1930 to 1950 to be one of the largest centers of leprosy research in the world, he served in prominent positions as Head of the Epidemiology Unit, Director of the Division of Sanatoriums and, later, of Leprosy Dispensaries. The depth of his professional knowledge acquired in the field of leprology led to his greatest scientific contributions, with approximately 300 publications in the Country and abroad, and his recognition as one of the world's greatest leprologists.

Beyond these administrative positions, he kept the role of director, concomitantly with de position of Head of the Department of Dermatology, both at FMRP/USP. His career reached its higher point with the international recognition of his activity as a leprologist, from December 30, 1961 to June 30, 1972, in the position of expert and Head of Leprosy Unit at the World Health Organization, after an international public competition held in Geneva, Switzerland.

His valuable academic production was crowned with contributions in describing the clinical course and epidemiological evaluation of the endemia of leprosy in our Country. In that sense, the Brazilian Treaty of Leprology and Compendium of Leprology were published, both in coauthorship with Abrahao Rotberg, constituted a landmark in the study of the disease. Prof. Bechelli was also one of the leaders in the proposition of the Brazilian Classification of Leprosy, that came to be adopted at a world level. Among the 275 works that he published, many of which with original contributions and some with ultramicroscopic dermatoses, he wrote 12 award winning monographs. Besides the above mentioned contributions, one should emphasize his authorship of the chapters "Premunition der Lepra" and "Behandlung der Lepra" in the monumental Handbuch der Haut und Geschlechtskrankheiten, de Jadassohn, republished by Marchionini. In the book of Veronesi, on infectious and parasitic diseases, he wrote the chapters on leprosy, bubo and pinta. He also collaborated in other foreign textbooks, such as that of Dharmendra and 
os de Dharmendra e de Chatterjee, e em Theory and Practice of Public Health, publicado pela Oxford-University Press.

$\mathrm{O}$ interesse pela ciência médica pode ser avaliado pela participação ativa em inúmeras sociedades médicas e em congressos brasileiros e estrangeiros, com os destaques seguintes:

Membro honorário das seguintes sociedades: Association des Léprologues de langue Française, Sociedade de Dermatologia y Sifiligrafia, Sociedade Cubana de Dermatologia y Sifiligrafia, Sociedade Brasileira de Hansenologia, Société de Pathologie Exotique, Sociedade Argentina de Dermatologia, Colégio Ibero-Latino-Americano de Dermatologia e Sociedade Brasileira de Dermatologia.

- Membro correspondente da: Societá Italiana di Dermatologia e Sifiligrafia, Société Française de dermatologie et Syphiligraphie.

- Afiliado da Royal Society of Medicine, London.

- Secretário Geral da II e III Confederação PanAmericana de Lepra (Rio, 1946 e Buenos Aires, 1951).

- Diretor do Manila Regional Seminar on Leprosy, bem como de outros eventos do WHO, West Pacific Regional Office, no Taiti.

- Membro do Advisory Board of the PA HO.

- Secretário-geral, vice-presidente e presidente da Sociedade Paulista de Medicina.

- Membro do Conselho da International Leprosy Association (1958-1982) e editor colaborador do International Journal of Leprosy.

- Coordenador do Comitê de Controle de Lepra no X Congresso Internacional de Lepra - CIL, Bergen, 1973.

- Coordenador da sessão sobre Epidemiologia e Controle no XI Congresso Internacional de Lepra, México, 1978; membro do Comitê de Epidemiologia e Controle nos CILs de Havana, 1948, e Rio de Janeiro, 1963.

- Membro do Comitê de Imunologia do VI Congresso Internacional de Lepra de 1952, em Madri, e de VII Congresso em Tóquio, 1958.

Ao concluir as atividades junto à OMS, em julho de 1972, assumiu a chefia da Divisão de Dermatologia do Departamento de Clínica Médica da FMRP/USP até março de 1982, quando recebeu a aposentadoria compulsória. No entanto, embora aposentado, continuou trabalhando na faculdade, como professor colaborador da disciplina de dermatologia. Foram 14 anos de atividades voluntárias, por ele relatadas com as seguintes palavras: "Trabalhei sem receber para poder compensar a Faculdade pelos anos em que fiquei afastado e me dedicando à Organização Mundial de Saúde". Anualmente cooperou com o Prof. Cottenot no curso de aperfeiçoamento em leprologia, em Paris.

A Divisão de Dermatologia da Faculdade de Medicina de Ribeirão Preto deve muito de sua excelência no ensino e prática da especialidade ao mestre Bechelli. O reconhecimento de seu importante papel na construção da de Chatterjee, and in Theory and Practice of Public Health, published by the Oxford-University Press.

His interest in the medical science can be measured by his active participation in countless medical societies and in Brazilian and foreign Congresses, with the following prominent societies:

- Honorary member of the following societies: Association des Leprologues de langue Française, Sociedade de Dermatologia y Sifiligrafia, Sociedade Cubana de Dermatologia y Sifiligrafia, Sociedade Brasileira de Hansenologia, Societe de Pathologie Exotique, Sociedade Argentina de Dermatologia, Colegio Ibero-Latino-Americano de Dermatologia e Sociedade Brasileira de Dermatologia

- Corresponding member of: Societa Italiana di Dermatologia e Sifiligrafia, Societe Française de dermatologie et Syphiligraphie.

- Affiliated to Royal Society of Medicine, London.

- General Secretary of the II and III Confederação

Pan-Americana de Lepra (Rio de Janeiro, 1946 and Buenos Aires, 1951).

- Director of Manila Regional Seminar on Leprosy, as well as other events of the WHO, West Regional Pacific Office, in Tahiti.

- Member of Advisory Board of the PA HO.

- General secretary, vice-president and president of the Sociedade Paulista de Medicina.

- Member of Council of International Leprosy Association (1958-1982) and collaborating editor of International Journal of Leprosy.

- Coordinator of the Leprosy Control Committee at the X International Congress of Leprosy - ICL, Bergen, 1973.

- Coordinator of the session on Epidemiology and Control at the XI International Congress of Leprosy, Mexico, 1978; member of the Committee of Epidemiology and Control in the ICLs of Havana, 1948, and Rio de Janeiro, 1963.

- Member of the Committee of Immunology of the VI International Congress of Leprosy of 1952, in Madrid, and VII Congress in Tokyo, 1958.

On concluding activities at the WHO, in July 1972, he assumed the position of Head of the Dermatology Division, Department of Clinical Medicine FMRP/USP until March 1982, when he received compulsory retirement. However, although retired, he continued working at the university, as a collaborating professor of the Dermatology course. These were 14 years of voluntary work, described by him in the following words: "I worked without payment in order to compensate the University for the years that I was not present, while being devoted to the World Health Organization". Every year, he assisted Prof. Cottenot in the leprology specialization course, held in Paris.

The Dermatology Division, at the Faculty of Medicine of Ribeirao Preto owes much of its excellence in the teaching and practice of the specialty to master Bechelli. 
história desse serviço, e até mesmo da própria instituição, veio por meio de inúmeras homenagens. Em 1994, recebeu o título de Professor Emérito da FMRP/USP. Em 1991, o Centro Acadêmico da FMRP fundou a Liga de Combate à Hanseníase Professor Luiz Marino Bechelli. Em 1997, a Divisão de Dermatologia da Faculdade, localizada no quarto andar do Hospital das Clínicas de Ribeirão Preto, passou a ser nomeada Divisão de Dermatologia Professor Luiz Marino Bechelli. No Congresso Brasileiro de Hansenologia, em Foz do Iguaçu, pôde ler a inscrição nas camisetas de todos os estudantes: Liga de Combate à Hanseníase L.M. Bechelli.

Outra significativa homenagem lhe foi prestada pela Sociedade Brasileira de Hansenologia, da qual foi um dos fundadores, no ano de 1999.

Casado com Laura Bechelli, mãe de seus seis filhos e companheira extraordinária, também responsável por seu sucesso, ficou viúvo em 1978 e, em 1982, casou-se com Maria Helena Machado Bechelli, professora associada da Escola de Enfermagem de Ribeirão Preto, USP; nela encontrou todo apoio e estímulo para o trabalho científico. Bechelli dizia que fora contemplado com dois grandes prêmios da loteria.

Teve cinco filhas e um filho, médico, assistente estrangeiro da Universidade Claude-Bernard, Lyon, França, professor associado de psiquiatria da Faculdade de Medicina de Teresópolis e secretário-geral da Sociedade Brasileira de Psiquiatria Biológica. Oito netos, dos quais três médicos, e um deles dermatologista, e uma bisneta completam sua família.

Nós, da Divisão de Dermatologia do Departamento de Clínica Médica da FMRP, unidos aos hansenólogos e dermatologistas deste país, agradecemos toda contribuição que seu trabalho trouxe para o conhecimento da hanseníase e outras dermatoses, e, espelhados em sua dedicação, respeito ao paciente e imensa capacidade científica, esperamos dar continuidade a seu grandioso trabalho, e evocamos que sua existência seja acompanhada pela paz e serenidade merecidas.

Norma Tiraboschi Foss
The recognition of his important role in the construction of the history of this service, and even of the institution itself, came through countless homages. In 1994, he received the title of Professor Emeritus of FMRP/USP. In 1991, the Academic Center of FMRP founded the League of Combat Against Leprosy Professor Luiz Marino Bechelli. In 1997, the University's Dermatology Division, located on the fourth floor of the Clinicas Hospital of Ribeirao Preto, was renamed Division of Dermatology Professor Luiz Marino Bechelli. In the Brazilian Congress of Leprosy, in Foz do Iguaçu, one could read the insignia on all the students' shirts: League of Combat Against Leprosy L.M. Bechelli.

Another significant homage was paid to him by the Brazilian Society of Leprology in 1999, of which he was one of the founders.

Married to Laura Bechelli, mother of their six children and extraordinary companion, she was also responsible for his success, he became a widower in 1978 and, in 1982, he married Maria Helena Machado Bechelli, associate teacher of the Ribeirao Preto School of Nursing, USP; in her he found all the support and incentive for scientific work. Bechelli affirmed that he had won two great lottery prizes.

He had five daughters and one son, a doctor, foreign assistant of the University Claude-Bernard, Lyon, France, associate teacher of psychiatry at the Teresopolis University of Medicine and general secretary of the Brazilian Society of Biological Psychiatry. Eight grandchildren, of which three doctors, one of these a dermatologist, and a greatgranddaughter completed his family.

We, at the Dermatology Division of the Clinical Medicine Department, FMRP, together with the leprologists and dermatologists of this country, demonstrate our gratitude for all the contribution that his work has brought for knowledge on leprosy and other dermatoses, and seek to reach the same dedication, respect for the patient and immense scientific capacity. We hope to continue his grandiose work, and we pray that his journey continues with deserved peace and serenity.

Norma Tiraboschi Foss

\section{REFERÊNCIAS / REFERENCES}

1. Bechelli LM. Memorial apresentado à FMRP/USP, para o Concurso de Professor Catedrático. Ribeirão Preto, 1960.

2. Azulay RD. Jubileu do Prof. Luiz Marino Bechelli (Editorial). An Bras Dermatol. 1990;65: 3-4.

3. Rossini C, Forgerini E. Medicina e Fé - Dr. Luiz Marino Bechelli. In: Mestres da Dermatologia Paulista. $1^{\text {a }}$ ed. São Paulo: JSN Editora Ltda; 2002. p.80-103.

ENDEREÇO PARA CORRESPONDÊNCIA: / MAILING AdDRESS: Profa. Dra. Norma Tiraboschi Foss Faculdade de Medicina de Ri beirão Preto - USP Av. Bandeirante, 3900 - 14049-900 Ribeirão Preto - SP Fone: (16) 602-2446 / Fax: (16) 633-0236

E-mail: ntfoss@fmrp.usp.br 